\title{
APPROACH OF THE ROMANIAN ECONOMY TO THE WEST AND ITS CONSEQUENCES
}

\author{
Akira UEGAKI* \\ (Seinan Gakuin Univ.)
}

\section{Introduction}

The approach of the Romanian economy to the West had already begun at the beginning of the 1960's. What caused this movement was the SovietRomanian conflict in the CMEA which had made progress under the surface at that time. In 1960 the share of the OECD countries in the Romanian import and export was $23.6 \%$ and $21.3 \%$ respectively, but those figures rose to $39.5 \%$ and $31.9 \%$ by 1970 ([11] p.172).

Thus the development of the approach of the Romanian economy to the West in the 1960's is significant enough to pay attention to, but in this paper the period after 1971 is examined in detail, though being based on the development in the 1960's for its premise. This is so because events which occurred on Romano-Western economic relation after 1971 were different structurally from those in the 1960's.

\section{Trends of Trade}

Table 1 shows the amount of Romanian trade with the OECD countries

* I would like to thank Professor Hitoshi Asao, Professor Sei Fujita, Professor Keiji Ide, Professor Yoshiaki Nishimura, Professor Shohichi Sugimoto and Professor Shojiro Tokunaga for their helpful comments expressed at two scientific meetings where the original version of this paper was read. I also wish to thank Professor Harshel C. Johnson for his useful help in improving my english. Nevertheless, I bear all responsibility for the opinions and english in this paper. 
AKIRA UEGAKI

Table 1

\begin{tabular}{lccccc}
\hline & $\begin{array}{l}\text { Romania's } \\
\text { export } \\
\text { (US } \$ 1000)\end{array}$ & $\begin{array}{l}\text { annual growth } \\
\text { rate }(\%)\end{array}$ & $\begin{array}{l}\text { Romania's } \\
\text { import } \\
\text { (US } \$ 1000)\end{array}$ & $\begin{array}{l}\text { lannual growth } \\
\text { rate }(\%)\end{array}$ & $\begin{array}{l}\text { balance } \\
\text { (US } \$ 1000)\end{array}$ \\
\hline 1971 & 624428 & & 755103 & & -130675 \\
1972 & 792115 & 26.9 & 986237 & 30.6 & -194122 \\
1973 & 1095934 & 38.4 & 1348925 & 36.8 & -252991 \\
1974 & 1578351 & 44.0 & 2042948 & 51.5 & -464597 \\
1975 & 1662253 & 5.3 & 1992748 & -2.5 & -330495 \\
1976 & 1971734 & 18.6 & 2014596 & 1.1 & -42862 \\
1977 & 1910981 & -3.1 & 2341950 & 16.2 & -430969 \\
1978 & 2370381 & 24.0 & 3017965 & 28.9 & -647584 \\
1979 & 3267109 & 37.8 & 3767284 & 24.8 & -500175 \\
1980 & 3504894 & 7.3 & 3887579 & 3.2 & -382685 \\
1981 & 3592847 & 2.5 & 3035436 & -21.9 & 557411 \\
1982 & 2618358 & -27.1 & 1670029 & -45.0 & 948329 \\
1983 & 2810193 & 7.3 & 1288580 & -22.8 & 1521613 \\
1984 & 3789591 & 34.9 & 1393291 & 8.1 & 2396300 \\
\hline
\end{tabular}

and their annual growth rate. From this table can be found some interesting features of the trends of Romanian trade with the West. Firstly, though in the 1970's Romania's balance of payment was in deficit, after 1981 Romania acquired a large amount of surplus, mainly made by the rapid decrease of import. This reflects the change of policy of the Romanian government. Secondly, the rapid growth of Romanian trade with the West in the 1970's was interrupted by the stagnation in the middle of 1970's. This suggests that the cause of the growth in the first half of the 1970's might be different from that in the second half of the 1970's.

Fig. 1 and 2 show the structural change of Romanian trade with the OECD countries by the SITC (the Standard International Trade Classification of the UN). Fig. 1 makes it clear that oil \& oil products (main items of SITC 3) have expanded their share in Romanian export to the OECD countries throughout the period while the share of food and live animals (SITC 0 ) has been reduced. Besides, Fig. 1 tells the continuing importance of miscellaneous manufactured articles (SITC 8) in Romanian export to the OECD countries. 
ROMANIAN ECONOMY AND THE WEST

Fig. 1. Romanian Export to OECD

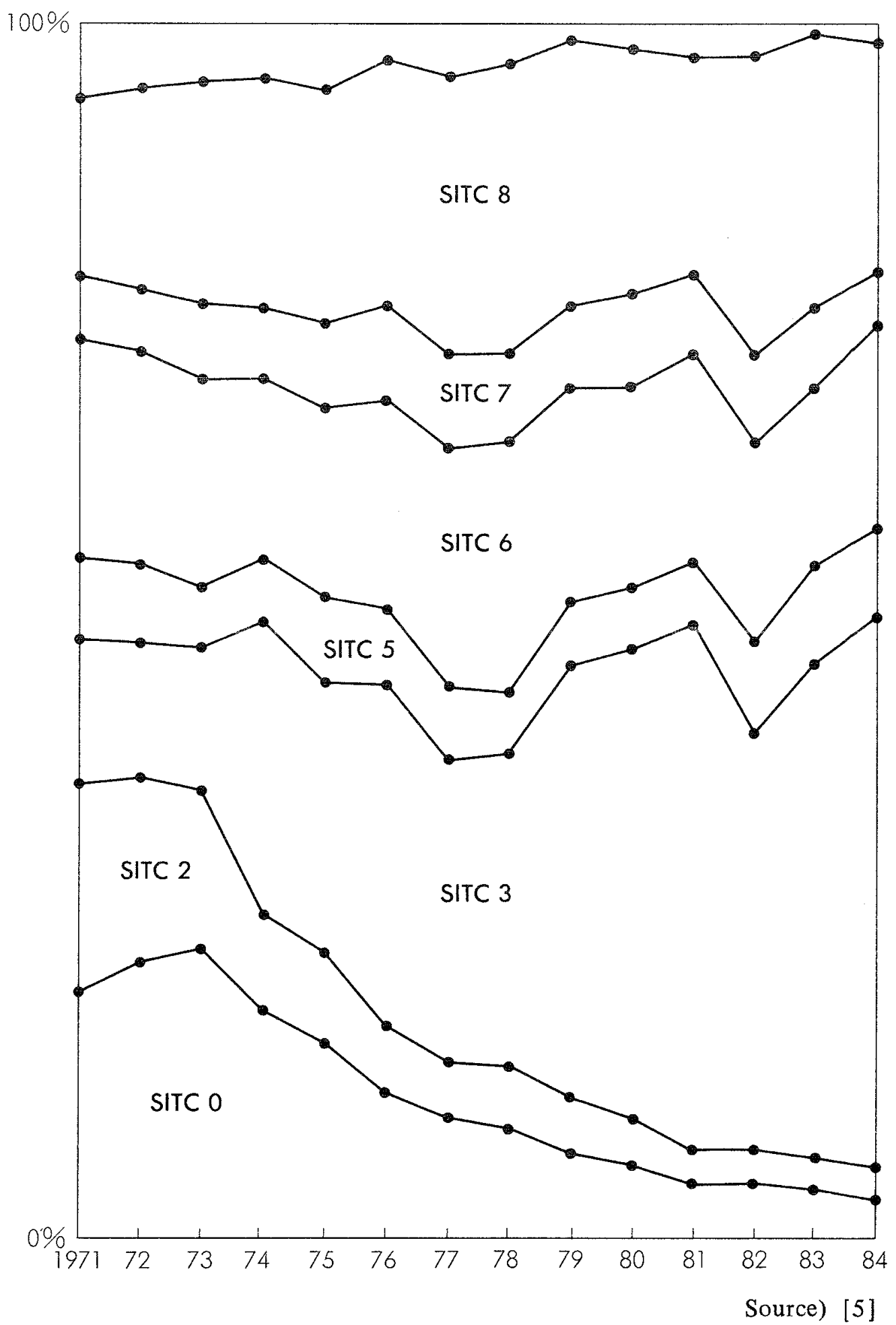

From Fig. 2 it can be easily realized that machinery and transport equipment (SITC 7), which had been the main items of Romanian import from the 


\section{AKIRA UEGAKI}

Fig. 2. Romanian Import from OECD

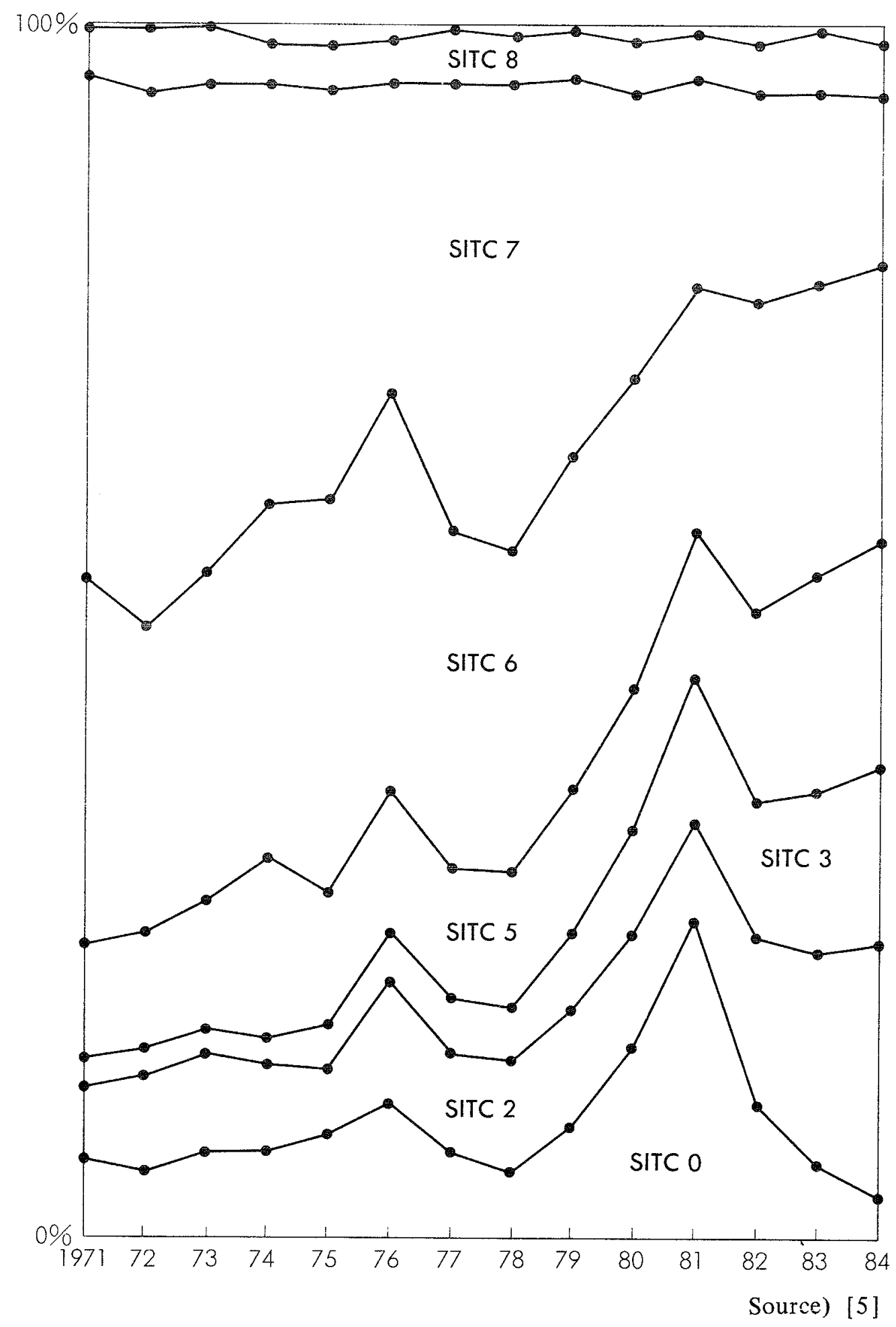

OECD countries until 1978 with the exception of 1976 , began to lose its share from 1979. At the same time it shows that Romania imported a large 
Fig. 3. Romanian Trade Performance with OECD

(a) $1971-1975$

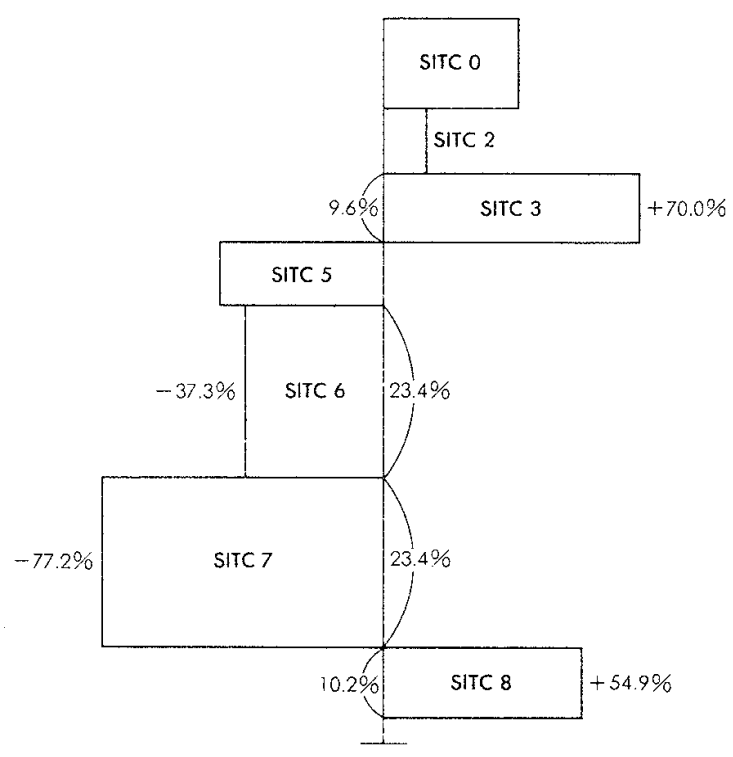

(c) $1981-1984$

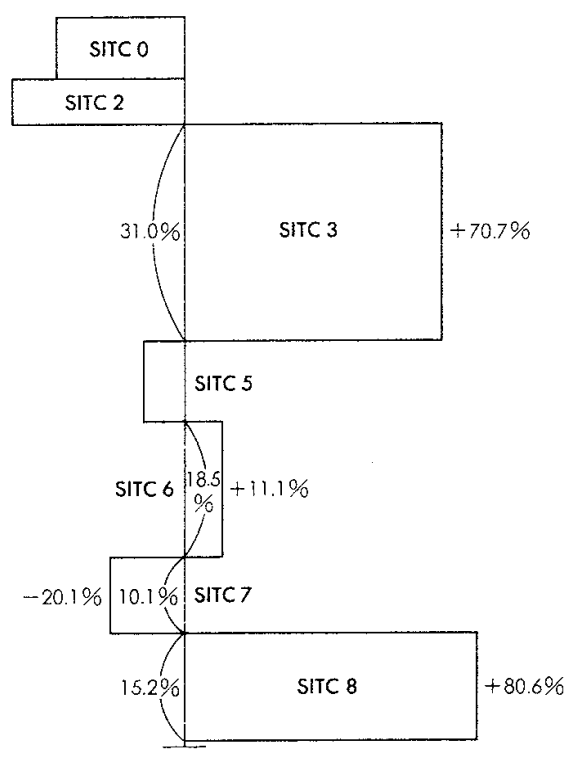

Source) [5] (b) $1976-1980$
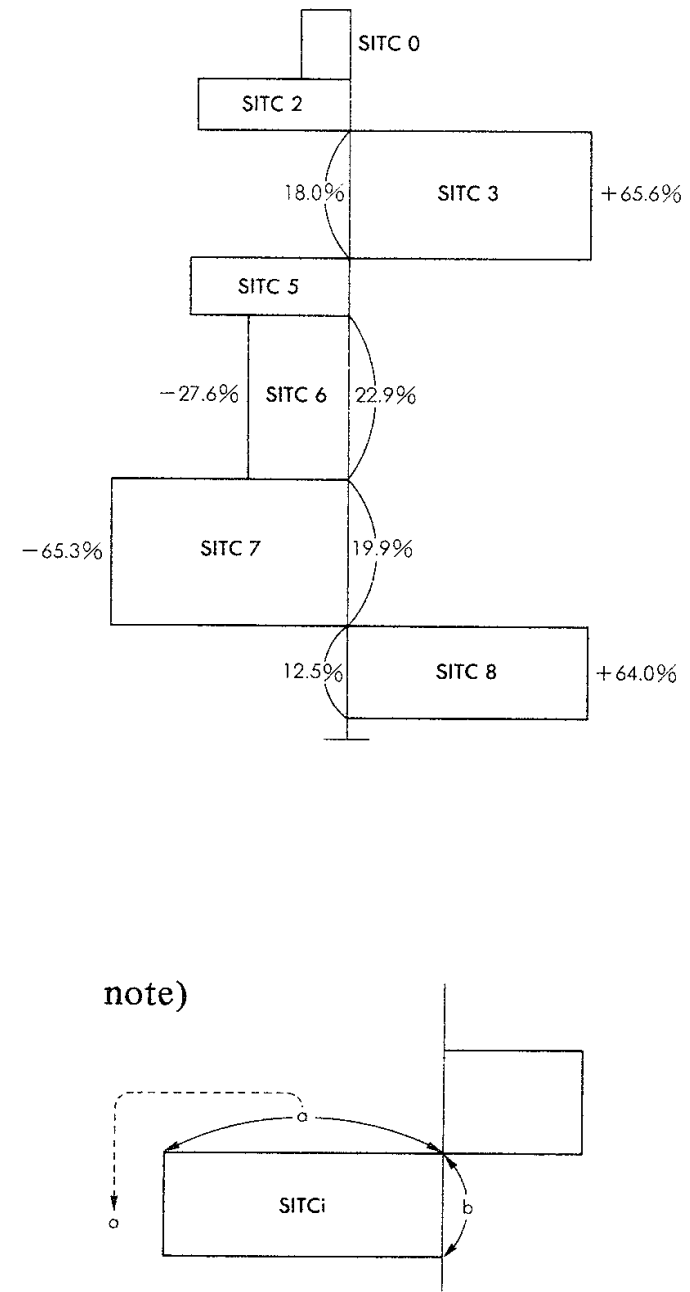

$a=(E i-l i) /(E i+l i)$

$b=(E i+l i) / \Sigma(E i+l i)$

Where Ei=Romania's Export of SITCi

$\mathrm{Ii}=$ Romania's Import of SITCi

amount of foods and live animals (SITC 0), most of which were cereals, from the OECD countries in 1980 and 1981. Fig. 2 also shows that the share of manufactured goods (SITC 6) continued to be significant from 1971 to 1984.

Fig. 3(a)-(c) are devised to crystallize the above mentioned trends visually. 
AKIRA UEGAKI

Table 2 Share of the West in Romanian Trade (\%)

\begin{tabular}{ccccc}
\hline & 1970 & 1975 & 1980 & $1983^{*}$ \\
\hline Romania's export & 31.9 & 34.7 & 35.4 & 35.8 \\
Romania's import & 39.5 & 43.4 & 31.0 & 19.0 \\
\hline$*$ ) & Provisional & & & \\
Source) & {$[11]$ p.172 } & & &
\end{tabular}

According to these, in the first half of the 70's Romania exported foods and live animals (SITC 0), crude materials (SITC 2), mineral fuels and related materials (SITC 3) and miscellaneous manufactured articles (SITC 8) and imported chemicals (SITC 5), manufactured goods (SITC 6) and machinery and transport equipment (SITC 7). But in the second half of the 70's she became a country which had to import even foods and crude materials and could export only SITC 3 and SITC 8 . In the second half of the 70's, though Romania expanded her export of SITC 3 and 8 and cut import of SITC 5, 6 and 7 slightly, she could not get a surplus in balance of payments because SITC 0 and 2 became import items. That SITC 0 became an import item means bad performance of Romanian agriculture and that SITC 2 became an import item reflects a shortage of domestic crude materials to feed the high rate of industrialization at that time.

In the 80's the structure of Romanian trade with the West was drastically changed. The deficit generated in the items of 5,6 and 7 was largely reduced and the amount of trade of these items also became smaller. On the other hand, the ratio of surplus and the share of trade of SITC 3 and 8 grew very much. Therefore, Romania could gain a large surplus in the 80's.

Meanwhile, the share of the West in the whole Romanian trade has fluctuated as shown in table 2. On the import side, the share of the West rose to $43.4 \%$ by 1975 and then fell sharply to $19 \%$ by 1983 . On the export side, the share rose from $31.9 \%$ in 1970 to $34.7 \%$ in 1975, but afterwards it had not changed so much until 1983.

From all of this it seems to be suitable for the study to divide the period into three stages: 1971-1975, 1976-1980, 1981 and after. 


\section{Development of the Romano-Western Relationship in the First Half of the 70's.}

In the first half of the 70's important steps in the approach of the Romanian economy to the West were her affiliation with the GATT (1971), issue of bills on joint ventures (1971/1972) and affiliation with the IMF and the World Bank (1972).

The purpose of the affiliation with GATT which had been prepared in the end of the 60's and was approved by the GATT session of October 1971 ([20] p. 127) was to get MFN (Most Favored Nation) treaties of other GATT countries and to trade with western countries without any discriminative condition (ibid. p. 130). Already in 1969 (namely after the invasion of the Warsaw Pact Army into Czechoslovakia) an official of the Romanian government referred to advantages to join multilateral institution of international trade such as GATT. He said that one of the advantages was the increase of operational stability in foreign trade thanks to unconditional application of MFN clauses ([19] p.67). Therefore, the affiliation with GATT seemed to be motivated by the consideration of the Romanian authority that she had traded with the West under unfavorable conditions in the 1960's. In addition to that we must stress the change of atmosphere in the North-South trade at that time. From the end of the 1960's, under the influence of the Prebish report, developing countries were encouraged to develop by way of trading and given favored trading conditions such as GSP (Generalized System of Preferences), and to join GATT was a premise to get GSP.

Establishment of joint ventures in Romania and other countries was approved generally by article 58 of law no.1/1971 which was to regulate Romanian foreign economic relations comprehensively ([16] p.30) and the decrees no.424 and no.425/1972 set detailed rules of joint ventures (ibid. pp. 207-217). The decree no.424/1972 lists the following as the purpose of the establishment of joint ventures: "to implement certain objectives which contribute to the development of the national economy; to extend, modernize, and re-equip certain existing objectives; to accelerate the introduction of certain modern technologies; to raise the technical quality level of production and services; and to ensure a raised productivity of labour" (ibid. p.207). The decree also refers to the promotion of exports, expansion of markets, 
training of specialists and others as its purpose. In short, it was expected that joint ventures should contribute to the introduction of modern technology (hard and soft ones) into Romania and the exploitation and expansion of the export market for her products.

Though there were and are many joint ventures established in Romania and abroad based on the decrees, it is doubtful whether they could contribute to the above-mentioned purposes. First of all, very few of them are manufacturing enterprises located in Romania which could have direct influences on the Romanian economy. At the end of 1981 only 4 enterprises were manufacturing and located in Romania out of more than 70 joint ventures ([17] pp.117-140). Moreover even such enterprises, which are manufacturing and located in Romania, are said to have some problems. Resita-Renk company, which was built by the agreement between the Renk AG of Augsburg and the Romanian Uzinexportimport in 1973 and started operations in October 1976, is a good example. According to Radio Free Europe's report, this first West German-Romanian joint company was in great difficulties in 1978 and the capacity of the plant was not fully used. The report quoted the words of a German who was involved in the project that the inflexible, Romanian red tape administration, which hindered the implementation of decisions, was to be blamed for all the difficulties ([6] no.26/1978, p.16). Of course this may be a one sided estimation of the difficulties from the German side, but at least it can be said that modern western technology was operated under the Romanian type of management. This is one reason for the unsuccessful performance of joint ventures. The last thing that must be referred to concerning the joint ventures is the question, "Where does the merit lie for a western company to establish a joint venture with Romania?" Romania is a small country with 22.6 million citizens and not an attractive market for the West. The situation is very different from that of China.

Therefore joint ventures were doomed to failure from the beginning, but in the first half of the 70's the problems were not realized by the Romanian authority.

In 1972 Romania joined the IMF and the World Bank. Naturally it was anticipated that some ideological criticism would be thrown on Romania as a member of CMEA. The Romanian authority seemed to try to evade such 
criticism by stressing the fact that the IMF and the World Bank are institutions of the United Nations ([12] p.143) and by claiming that Romania would defend the interests of the developing countries in the IMF and the World Bank ([14] pp.27-28). But Romania did not join the IMF and the World Bank in order to help developing countries. The real intention of Romania is easily understood by the words of A. Berea, the Minister of Finance at that time. He said, "One of the main advantages to participate in the activity of the two international financial organizations is the possibility to enjoy the benefits of loans [of the IMF and the World Bank], whose sizes, terms and level of interest are more convenient than what could be obtained currently on the capitalist market" ([12] p.143). In addition to such direct advantages, he also asserted that Romania would be able to extend financial cooperation with member countries (ibid. p.144). In short, the motive of Romania in joining the two organizations was to introduce favorable loans of the IMF and the World Bank and then to get the money of other member countries of the organizations.

The affiliation with IMF and the World Bank has had stronger influence on the Romanian economy than the affiliation with the GATT and the issue of decrees on joint ventures. This made Romania a country that could start a new project without any consideration on balance of payments problems. This also can be estimated as a premise of involvement of the Romanian economy in the international financial system of the capitalist world, though the financial relations between Romania and the capitalist world in the first half of the 70's appeared only as official loans or finance accompanied by the usual trade transactions.

Thus in the first half of the 70's Romania started a bold policy towards the West not only to expand the scale of trade with the West but also to set up a new framework of the relation with the West. At the same time it is interesting that the words "participation in the international division of labor" can be found very often in Romanian economic literature of those days. The Romanian economists repeatedly gave emphasis to the advantages of the international division of labor ([20] p.126). Considering the fact that from the end of the 50's to the first half of the 60's Romania resisted "the socialist international division of labor" which Khrushchev wanted to create in the CMEA ([21] no. 2 pp.49-72), it is very ironical that Romania tried 
eagerly to participate in the "capitalist international division of labor" at that time.

\section{Unsound Features of the Relation in the Second Half of the 70's}

The conclusion of the U.S. - Romanian trade agreement in 1975 was the high point of the Romanian movement towards the West in the first stage and the springboard for new development. By this agreement Romania was granted MFN tariff status and came to be able to receive more credits from the Export-Import Bank (of the US) and the Commodity Credit Cooperation $(\mathrm{CCC})^{1}$ ([18] p.261). In addition, in 1976 some Romanian goods became eligible for duty free treatment under the GSP of the United States (ibid. p.240, p.260). The status of the MFN and the GSP made it much easier for Romania to export to the U.S. From 1975 to 1978, the average annual growth rate of Romanians export to the US was 37.5 percent (ibid. p.260). Furthermore in November 1976 a ten year agreement on economic, industrial and technical cooperation was signed between the United States and Romania ([2] 1977 p.385). These American policies can be interpreted as political measures to encourage the Romanian "independent" movement in the socialist world. Anyhow the Romano-Western economic relation moved to a new stage in the second half of the 70's by such American policies.

The outstanding characteristics of this new stage are Romania's increasing dependence on capitalist financial systems not only formally but also substantially. Romania's use of the IMF credit was 48 million SDR by the end of 1973, also 48 million by the end of 1974 and 88 million by the end of 1975 , but this amount sprung up to 238 million by the end of 1976 ([3] 1982 p.383). These credits encouraged capitalist commercial lenders to undertake to loan Romania. The growth rate of commercial credit was much higher than that of the IMF or other official credit. While the share of commercial credit in the Romanian debt was $42 \%$ in 1970, it was kept over the level of 60\% in the second half of the 70's and especially in 1979 marked

1. The Export-Import Bank of the US had already directed loans to Romania several times before 1975 ([6] no.18, 1974 pp. 20-21). 
$73.9 \%$ ([18] p. 264).

This trend was accelerated by the fact that in 1977 the oil balance (export of oil products minus import of crude oil) fell into deficit for the first time in the 70's ([3] 1982 p.383). This deficit compelled Romania to raise demand for western capital not only for building new projects but also for current expenditure. Terms on the international financial market, however, were very favorable for borrowers at that time. Western bankers were competing with each other to get a greater share. At the same time in capitalist financial markets communist countries were deemed to be safe borrowers under the assumption that nations do not go bankrupt and that communist states always repaid debt ([4] no.30 p.19). Moreover western bankers regarded the level of Romanian external debt as still manageable and thought that Romania's membership in the IMF and the World Bank represented a major positive factor in their risk assessment ([4] no.2 p.72). In fact, at that time the comparatively low spreads were obtained by Romania in Euro-borrowing operations (ibid.).

In 1977 Romania indtroduced Euro-credit for the first time (ibid. p.71). Thereafter Romania rapidly expanded credit from western private banks. While at the end of 1976 Romania's commercial debt to werstern banks was US \$ 936 million, by 1979 it went up to US $\$ 3,800$ million, that is, more than four times. This is the largest expansion among the USSR and the CMEA Six ([4] no. 18 p. 10).

Romania's increasing dependence on commercial credit was accompanied by the expansion of short term credit, the ratio of which in total of Romania's debt was around 50\% at the end of 1979 (ibid. p. 19). Afterwards this brought Romania to great difficulties.

Thus Romania's most important financial partner had been changed from official institutions such as the IMF and the World Bank or national states to shortsighted private organizations in the second half of the 70's. What was the reason for such a change? The key point of this change is an independent inclination of the Romanian authority which had been eager to have a free hand to take a high industrialization policy. Already in 1958, Romania accused the USSR of not extending favorable credit to Romania ([21] no.1 pp.270-273) and in 1962 claimed that she would introduce western credit (ibid. no. 2 pp.66-67). But conditions under which Romania could get loans 
from the IMF and the World Bank or national states were not so generous as the Romanian authority expected. In fact, the term of repayment and the rate of interest of such official loans were more favorable than those of commercial loans. But such an official organization would interfere in the way of using money. On the other hand, commercial lenders, especially short term lenders, would not poke their nose into other countries' affairs as long as they could expect to get the principal and the interest. Therefore commercial loans were seen as colorless by the Romanian authority which still continued high industrialization without any long-term perspective even in difficult conditions of the second half of the 70's. This is why Romania came to be addicted to introducing commercial loans in the second half of the 70's.

Thus in the second half of the 70's Romania moved to the stage in which unsound features of the Romano-Western relationship appeared openly.

\section{Crisis of the Romanian Economy and the New Phase of the Romano- Western relationship in the 80 's}

At the end of 1980, Romania's hard currency debt reached the level of US $\$ 9.2$ billion and it grew to 9.8 billion at the end of 1981 ([9] no.3, 1984 p.29). In the autumn 1981 a great deal of western short term credit suddenly leaked abroad ([3] 1982 p.385) and Romania was in difficulty. The Romanian government requested lender countries to accept rescheduling and an overall agreement was concluded at the Paris Club in July 1982. But it was not enough to rescue the Romanian economy from crisis and the second rescheduling was necessary in 1983 . These reschedulings checked the spread of the fire of crisis.

After that, President Ceausescu declared that Romania would not introduce foreign credit any more and in November 1984 he said that Romania would pay back foreign debt completely in the period of the next five yearplan ([23] p.28). Under the pressure of a large amount of debt and in the humiliation of rescheduling, Romania seemed to be compelled to renounce her development strategy that was to pursue high industrialization by introducing western capital and technology.

Already in 1981 the Romanian government started a dreadful policy 
to gain a trade surplus. The deficit of US $\$ 1,534$ million in convertible currency trade in 1980 was turned to a surplus of 204 million in 1981 and then grew to a surplus of 1,525 million in 1982. This trade surplus made it possible for Romania to repay a large amount of her debt. By the end of June 1984, Romania's hard currency debt (net) had dropped to 7.8 billion (a part of this decrease was due to the depreciation of the US dollar) ([1] 1984-1985 p.208).

Rescheduling is usually interpreted as a symptom of the destruction of a national economy, but considering the situation of other developing countries which suffer from debt problems and would not repay their debt at all, the performance of Romania's efforts to repay debt under the rescheduling can be estimated as evidence of high ability of the Ceausescu's Administration, though what has been brought to the Romanian people by this "ability" must be investigated. Anyhow it is ironical that only a highly centralized socialist state seems to be able to manage debt problems.

In the 1980's, some conflicts began to appear in the relation between Romania and the IMF. In June 1981, a stand-by credit was approved to issue to Romania, which was seen as a new step of the relation between Romania and the IMF. But this credit was not drawn out regularly, because the Romanian government could not meet the severe instructions that the IMF staff gave. At last in 1984 the Romanian government canceled a drawing of the credit and declared that Romania would not depend on stand-by credit any more. The Romanian authority interpreted the measures, which the IMF had recommended, as an intervention into Romanian internal affairs. In fact at the 13th Congress of the Romanian Communist Party held in November 1984, Ceausescu criticized the worldwide high rate of interest, indicated new measures to aid debt suffering developing countries and blamed the IMF's policy. Apparently he accused the IMF of intervening in the internal affairs of other developing countries, but there is no doubt that he was interested only in the "intervention" into the Romanian matter ([23] p.62-63). The IMF's money has proved not to be "colorless". Now the Romanian government is taking measures almost contrary to those which were carried out under the stand-by arrangement. The relation between Romania and the IMF is at a turning point.

Thus Romania is now trying to run away from the financial system of the 
capitalist world in which she was once involved.

\section{Influences of the Approach}

\section{[a] Structural Change}

What kind of influences have been exerted on the Romanian economy by her approach to the West?

As is said in Section 2, Romania's trade with the West had been in deficit in the 1960's. Faced with such a deficit problem in the beginning of the 70's, the Romanian political and theoretical leaders emphasized the necessity of a foundation of international economic relation based on the observance of national sovereignty, reciprocity and non-interference in internal affiars. They also stressed the importance of cooperation, especially in the sphere of science and technology, with other countries regardless of their socio-political system (see Article 1, Law no. 1/1971).

Already in July 1969, Ceausescu said, "We consider that victory of socialism in Romania and affiliation of Romania with the socialist world system need not lead to isolation of Romania from other countries in the world; on the other hand we consider it national, as well as international duty to develop collaboration with all the countries in the world, regardless of their social system" ([15] p.81). In February 1971, he openly accepted a role of western developed countries as supplier of machinery and equipment in the preceding five years (ibid. 84). But after that he became to give emphasis to the cooperation in production with the West in stead of the import from the West (ibid. pp.81-92). It can be interpreted that he aimed at the import substitution by introducing the western technology.

In July 1971 C. Burtica, Foreign Trade Minister at that time, pointed out that a negative influence on the balance of payments had been exerted by the fact that some branches (machine building industry, chemical industry) had not realized all the obligatory plans of export, especially export to western industrialized countries ([13] p.25). He also recommended some forms of cooperation with the western countries such as joint ventures in order to encourage export of chemical products and machinery to the rest of the world (ibid. pp.30-32). 
In fact according to a western source, the mechanical engineering and the chemical industries' share of the total number of industrial cooperation contracts with the West were $51.1 \%$ as of 1 June 1976 and $50.0 \%$ as of 30 September 1979 ([22] pp.104-105).

From all of this, the development strategy of the Romanian authority can be formalized as follows;

(1) to establish an equal right status by joining the GATT

(2) to introduce western technology by establishing joint ventures or other forms of cooperation

(3) to introduce western capital by joining the IMF and the World Bank

(4) to form an industrial structure, in which Romania need not import a large amount of chemical products and machinery from the West and she can even export them to the rest of the world, by using the advantages of the above mentioned conditions ((1)-(3)).

But according to Fig. 3, this strategy has not been realized. Chemical products (SITC 5) and machinery (SITC 7) are still import items. Fig. 4 (a)(e) show the Romanian trade with the OECD in machinery and transport equipment (SITC 7) in detail. These figures make it clear that the main items of SITC 7 remain as import items with the exception of road vehicles (SITC $78)^{2}$. The rushing industrialization of Romania in cooperation with the West in the 70 's only increased the import of power generating machinery, metal working machinery, electrical machinery and so on. The Romanian government failed in producing surplus in the trade of these items and import substitution of them was not progressed. Besides, these figures tell that a large part of surplus in the 80's was gained by forced reduction of import of machinery, not by some structural improvement in industry. Almost the same trends can be seen in the trade of the main chemical products (SITC 5) except manufactured fertilizers (SITC 56). In 1983 the share of machine, equipment and transport means of total Romanian export (not only to the West but also to the whole world) was the lowest in the European CMEA countries except for the USSR. As for chemical products, though the share was relatively high, it was not higher than GDR and USSR ([10] pp.299301).

2. But the amount of export of road vehicles is much smaller than the amount of import of other items. 


\section{AKIRA UEGAKI}

Fig. 4. Romanian Trade with OECD in Machinery (US\$1,000)

(a) SITC 71

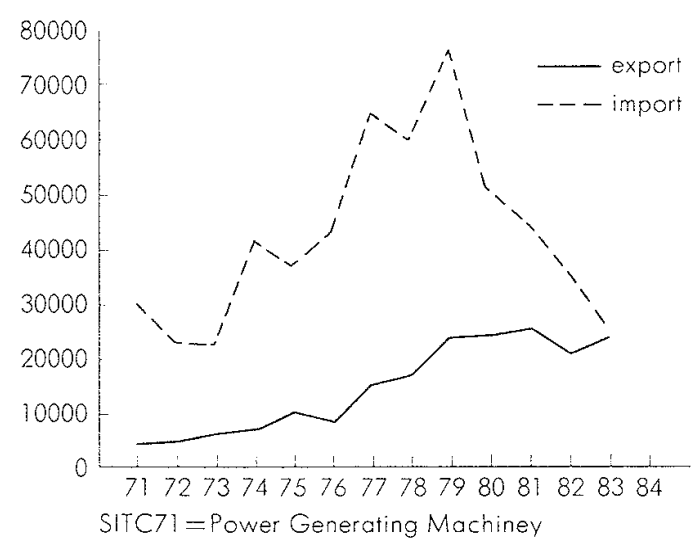

(c) SITC 74

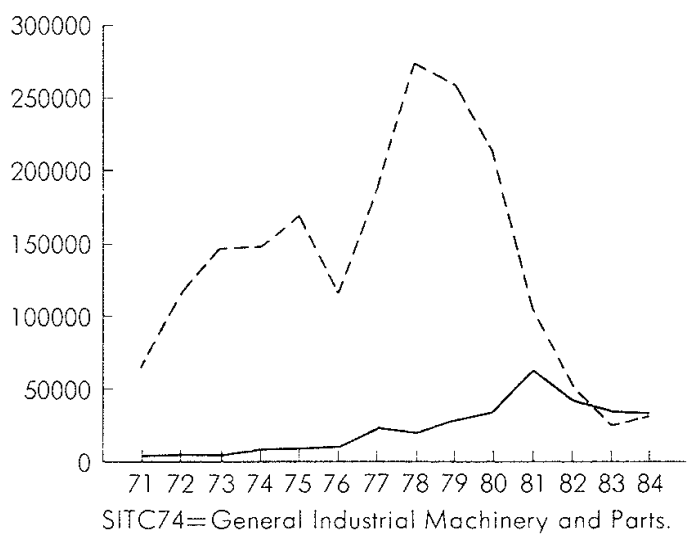

(e) SITC 78

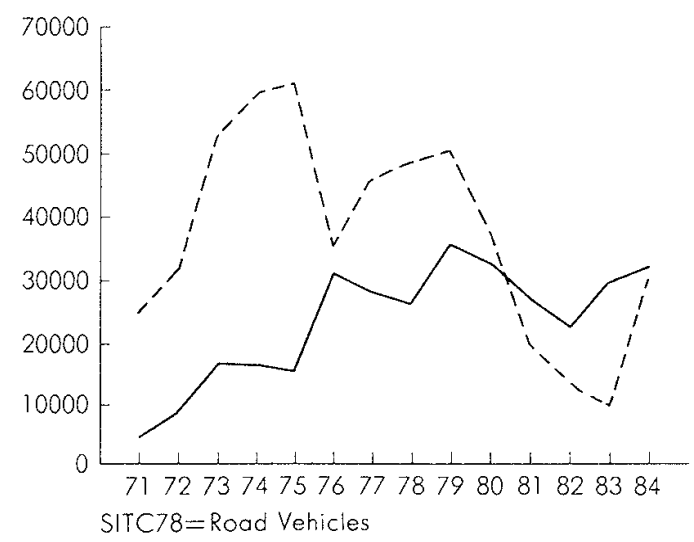

(b) SITC 73

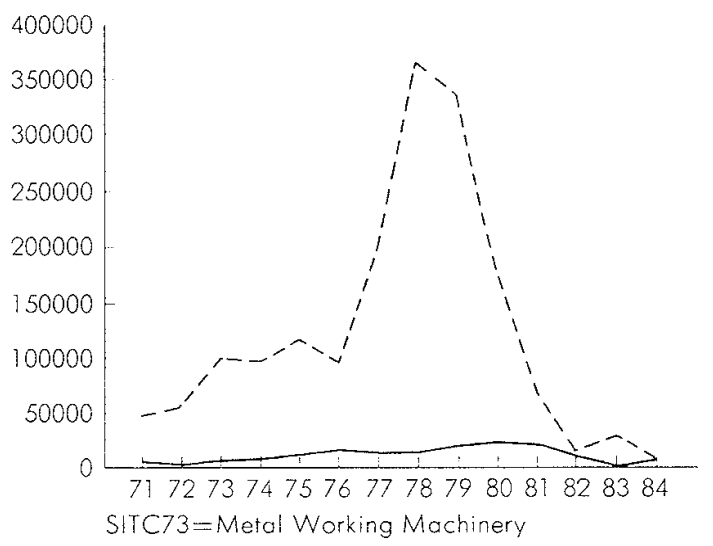

(d) SITC 77

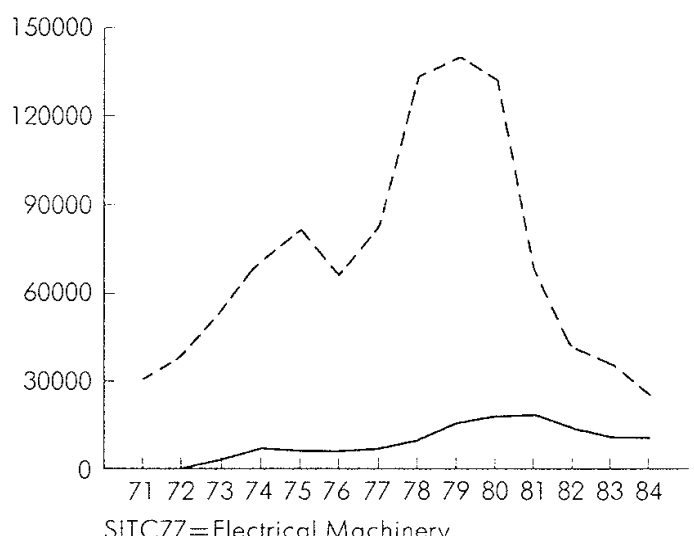

SITC77=Electrical Machinery 
Thus we can conclude that the approach of the Romanian economy to the West could not build a new industrial structure which the Romanian leaders expected to have in the beginning of the 70's.

\section{[b] Technology Transfer}

Since the Law no.1/1971, the Romanian government has encouraged many forms of industrial cooperation with the West in addition to joint ventures. Romania has been provided with a supply of licenses, delivery of plant, detachment of specialists and so on. According to a Romanian source, by the way of "cooperation and specialization in production", Romania has been provided with "new technology in the fields of: helicopters and aircraft from France and England; tools from Belgium; diesel and electric locomotives from England; buses and lorries from the F. R. of Germany; tractor from Italy; motors and compressors from the F. R. of Germany; passenger cars from France; cold rolling mills and sheet iron zinc-coating from Australia; fertilizers from Belgium; medical drugs from Switzerland; ceramic products and hydrated limestone from Italy; ball bearings from Japan; glass wool from the F. R. of Germany, etc." ([17] p.115).

But it is doubtful whether western technology could be assimilated to and diffused in the Romanian economy. For example, by 1983, Romania's production of passenger cars which the country was encouraged to develop by the help of capital and technology from France could not reach the level of the GDR and Czechoslovakia which were reluctant to approach the West ([10] p.80), and furthermore the number of export of road vehicles (including trucks and buses) to the West was the lowest in CMEA countries except for Bulgaria ([5] (import) 1984 p.80). This low level of car export reveals that a Romanian car is not appreciated as a quality one in the western market. Renault or Citroen's high technology was not assimilated to the plants in Pitesti or Craiova.

Many western businessmen and specialists who had a chance to see the inside of Romanian manufacturing plants point out that the Romanian managers do not see technology from a systematic point of view. They often combine Japanese equipment with West German equipment in the same plant considering only costs. Thus the latest western technology aften fails in 
exhibiting its potential. This is closely related to the problems of management mechanism.

\section{[c] Management Mechanism}

Can we find any symptom of change in the Romanian management mechanism, which has been regarded as highly centralized or Stalinist, in the course of the approach to the West?

Since Law no. 5/1978, an appeal that "workers' self-management and economic-financial self-control" must be strengthened has been heard very often. This "self-management" or "self-control" is a system in which an enterprise is regarded as a financially independent unit, its performance is estimated by value standard and workers in it can be provided with a premium according to their achievement ([7] no.13, 1978 pp.1-2, pp.6-8). So by reading provisions of the Law, this new system can be deemed to cope with the current system in other East European countries. It is likely that the making of this system was promoted by the approach of the Romanian economy to the West, because contacts with the western economy may make Romanians realize that introducing some system to bring about workers' voluntary is necessary.

But this was only on paper. In 1981 the Law of 1978 was amended to demand more severe discipline for workers in plants, which is thought to be related to the Polish crisis. Afterwards with the Romanian economy growing worse, the meaning of the word "self-" came to be an increase of workers' responsibility instead of an increase of workers' right.

Moreover after the Party conference at the end of 1982, the Romanian government and the Party came more and more to encourage the system "Acord Global". According to the Law of September 1983, this is a kind of piecework system with joint responsibility in which various contracts should be concluded on goals for production, cost reduction etc. between the workers' group and managers ([8] 13 Sep. 1983 p.3). "Self-management" and "Acord Global" are used to produce more and export more by the strengthening of workers' discipline.

These movements in the sphere of management mechanism in Romania must have been promoted by the demand of western lenders, "Repay the 
debt!" As is said in Section 3, western money was "colorless" for the Romanian authority but if western lenders felt that their principal and interest would be in danger, they would demand, "Repay the debt by resorting to any measures!", because the lent money was "colorless". Here we find an interesting relation to the effect that western logic not only preserves but also strengthens the oppressive management mechanism in Romania.

\section{References}

Periodicals

[1] Economic Commission for Europe (ECE), Economic Survey of Europe. Geneva.

[2] IMF, Annual Report on Exchange Arrangements and Exchange Restrictions. Washington, D.C.

[3] IMF, International Financial Statistics, Year Book. Washington, D.C.

[4] OECD, Financial Market Trends. Paris.

[5] OECD, Foreign Trade by Commodities (Series C). Paris.

[6] Radio Free Europe, Radio Free Europe Research, Romanian Situation Report. Munich.

[7] Revista Economica. Bucharest.

[8] Scinteia. Bucharest.

[9] Wiener Institut für Internationale Wirtschaftvergleiche (WIIW), Mitgliederinformation. Vienna.

Statistics

[10] Statisticheskii Ezhegodnik Stran-Chlenov SEV, 1984. Moscow.

[11] WIIW, Comecon Foreign Trade Data 1984. Vienna.

Books, articles and others

[12] Berea, A., Aderarea Romaniei la F.M.I. si B.I.R.D. Probleme Economice. (Bucharest) no.1 1973.

[13] Burtica, C., Adaptari Structurale ale Exporturilor Romanesti la Cererea Pietei Externe. Probleme Economice. no. 71971.

[14] Capatina, O. and Others, Republica Socialista Romania in Organizatii Economice Internationale. Bucharest, 1973.

[15] Ceausescu, N., Comertul Exterior si Cooperarea Economica Internationala. Bucharest, 1980.

[16] Chamber of Commerce and Industry of the SRR (Ch. of Com.), Romanian 
Foreign Trade Law. Bucharest, 1982.

[17] Ch. of Com., Economic and Commercial Guide to Romania. Bucharest, 1982.

[18] Droker, L. and John Martens, Romania: Performance and Prospects for Trade with U.S. and the West. Joint Economic Committee, Congress of the United States, East-West Trade: the Prospects to 1985. Wahington, D.C. 1982.

[19] Negru, R., Contributii la Problema Bilateralismului si Multilateralismului in Relatiile Economice Internationale. Probleme Economice. no.2 1969.

[20] Petrescu, M., Aderarea Romaniei la G.A.T.T. Probleme Economice. no.12 1971.

[21] Uegaki, A., Socialist International Division of Labor and Socialist Industrialization - Romanian Revolt 1956-1964 - (1), (2) (in Japanese). Keizaigaku Ronshu (Review of Economics). (Seinan Gakuin Univ., Fukuoka) (1) $=[$ vol.20 no. $2 / 3$ 1985], (2) $=$ [vol. 21 no. 1 1986].

[22] Zaleski, E. and Helgart Wienert, Technology Transfer between East and West. Paris, 1980.

[23] Congresul al XIII al Partidului Comunist Roman. Bucharest, 1985. 